\title{
Stylistics Study and Pitutur Luhur on Tembang Tayub
}

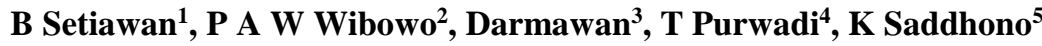 \\ \{1uset.74@yahoo.com, ${ }^{5}$ kundharu.uns@gmail.com\} \\ 1,2,3,4,5 Universitas Sebelas Maret Surakarta, Indonesia
}

\begin{abstract}
This research specifically aimed to analyze the language style of Tembang Tayub in Sobo Village, Grobogan using stylistics approach. This research also analyzed about pitutur luhur of Tayub Performance. the method used in this research is descriptive qualitative. the data resources of this research were event (performance of Tayub), informant (chairman of Tayub performance, society, and Javanese language teacher in Vocational High School), and document (song lyrics of Tembang Tayub). Data collected technique used observation, in-depth interview, and content analysis. the collected data then analyzed by interactive technique which has three phases, that are data reduction, data display, and conclusion drawing. The result of this research found that Tayub performance contains pitutur luhur which can be reflected from song lyrics of Tembang Tayub, mutual cooperation values from the character. Tayub performance also contains philosophical and symbolic values. From that reason, Tayub performance has relevance with Javanese language learning material in Vocational High School, especially in Javanese performing art subject. By introducing some of the Javanese performing art to the student also can be an alternative way to preserve the Javanese culture.
\end{abstract}

Keywords: Stylistics Study, Pitutur Luhur, Tembang Tayub, Javanese Language Learning in Vocational High School.

\section{INTRODUCTION}

Langen Tayub performance is usually held at traditional ceremonies (weddings, thanksgiving, etc.).It was originally for the welcoming ceremony of the great guests in the palace. The beginning of the performance was opened by the Gambyong dance. Gending(song) or poetry of the tayub itself actually contained advice, satire, and even narrated the warrior struggle. Tayub performance is indeed no stranger, especially for residents in Blora, Rembang, Pati, Grobogan, and Sragen areas. Tayub is a performing art that is considered as folk art that emerges from rural farming communities. Tayub is different from the palace classical dance such as bedaya. The tayub performance is usually held by the residents to enliven the circumcision ceremony, the wedding, even the commemoration of the Independence Day is celebrated by renting the tayub performance [1].

Tayub was originally an expression of joy for welcoming guests and part of the people's party. This performing art is in the form of a paired dance between ledhek (female dancer) with male dancers as penayub (person who invited to dance). About the term tayub itself there are several opinions. Some say that it comes from the words ditata cik ben guyub (arranged to be compact). Sukarno SH, the Chairperson of Pepadi Blora stated that the phrase'tatanan sing 
guyub'means behavior and movement must be compact physically and mentally. Compact between waranggana dancers with the male dancers and gamelan musicians. Actually, it issymbolic which means all in work must be compact [2].

Tayub is a folk art, not a royal art. But Warsit, the Chair of Blora Regional Representative Council, called tayub as a noble art, because it was originally a dance that was presented to the great guests in the palace. But when in the Dutch colonial era, tayub was misused. The dance performance at that time was infiltrated with liquor, it was purposed to disrupt the sense of unity. With drunkenness, people can be easily offended, fight, and so on. "Since then the people's judgement of tayub has become negative," (Interview with Warsit, S.Pd as the Chairperson of Blora Regional Representative Council on Sunday, July 15, 2018, 10:25 WIB) The tayub performance that develops in the area where it lives is an art that is already familiar for its life, because it is often performed in traditional and thanksgiving events for the community who hold a ceremony. The tayub performance that develops from a deep scientific perspective has much motives and meanings contained in each performance. This can be seen and studied from the songs sung by warangganalledhek (dancers), the costumes, the gamelan or musical accompaniment [3].

\section{RESEARCH METHOD}

The approach used in this study was qualitative approach. Arikunto mentioned that, "qualitative research is a descriptive study because it tries to describe the data with words or sentences which separated by some categoriesto obtain conclusions". Qualitative research requires the researcher investigate the phenomenon that occurs naturally with its complexity. This study used content analysis technique. Fraenkel and Wallen stated that, "content analysis is a technique that researchers can use to study human behavior indirectly through analysis of their communication such as: textbooks, essays, newspapers, novels, magazine articles, songs, advertising images and all types of communication that can be analyzed".

\section{RESULT AND DISCUSSION}

There are numbers of indigenous culture that continue to survive today and practiced by society. The cultures are varying from folk art to social dance [4]. In Tulungagung, for example, there are a number of indigenous culturesthat still survive and continue to be preserved. Such as the Tiban performance, the ceremony of asking for rain, Tulungagung Reyog, Jaranan Sentherewe, Tayub, and many more. The actors who play a role in thus performing arts are the people of Tulungagung, and obviously they are people who are very firm to their ancestral heritage. Tayub performance first appeared in Surakarta in the $19^{\text {th }}$ Century, at that time Tayub performance was an entertainment for all people, especially the nobles and village leaders who were holding the wedding party and circumcision.

Tayub is a fertility ritual art that is important for rural communities whose lives are still dominated by agrarian culture. In this case, the ledhek dancers have an important role in ritual ceremonies for fertility and safety. The fertility which correlated with harvesting events is often associated with Dewi Sri as the Goddess of Fertility. The paired dance scene in Tayub is often spiced with gestures such as kissing which symbolizes the relationship between male and women strength which expected to stimulate the strength for conception or offspring. In general, many Javanese arts have mystical nuances, one of which is the Tayub dance. Supposedly, the Tayub dancers used mystical methods, such as susuk (magical implants)to attract the audiences $[5]$. 
Tayub is a traditional folk performing art in the form of social dance which performed spontaneously, followed by tembang/gendhing (songs)which accompanied by gamelan. The tayub performance is an entertainment show to enliven the wedding and circumcision parties, so that the people who attend get entertained. The word tembang or gendhing is a term that used in the Javanese, Sundanese, and Balinese regions. Outside the ethnicity (Javanese, Sundanese, Balinese), in general, the word tembang/gendhing mentioned as lagu daerah (folk songs). Tembang means poetry or songs. The tembang lyric usually contain stylistic section and educational values which interesting to study further [6].

Stylistics can be included as a field of applied linguistics. In a broad sense, stylistics is a way of expressing theory and formal analysis methodology of literature text. Stylistics also mentioned as a meeting point between language macro analysis and literature macro analysis. Stylistics examine literature discourse from linguistic orientation and the link between linguistics on one side and literary criticism on the other [7]. Morphologically, it can be said that the component of style relates to literary criticism while the component of istics related to linguistics.

In addition to the linguistic elements, the presence of religious elements in literature is something that is comprehensive even the literature grows from religious things. Religion is the encouragement of the creation of a literary work, as a source of inspiration and at the same time often make the literature cease to religion. Religious values aim to educate people to be better according to religion guidance and always remember God [8]. Character education has a higher meaning than moral education because it not merely teaches the right and wrong, but character education instills the good habits so students become aware of what is good and wrong, and able to feel and do good habits.

The development of noble values through tembang and songs for children, especially at the kindergarten and elementary school age is very appropriate and should have been implemented for a long time. Because Javanese tembang and folk songs in each region contain noble values, while kindergarten and elementary school-age children are like white cloths that are still clean, should be equipped and forged with noble teachings to forming behavior, attitudes, characters. Character in simple language is equated with personality, behavior, temperament, or characteristics of a person that reflects one's identity [9]. The character development in human life becomes something important and strategic because character is often identified with morals.

The 2003 National Education System Law, notion that the goals of national education are include developing the student potency to have intelligence, personality, and noble character. On May 2, 2016, the Minister of National Education declared the commencement of national character education. National character education is important and becomes the focus of national education. I do not want to elaborate on the polemic of the national education system, but I invite all components of educators who are none other than teachers, to join hands, unite all creativity, sense and intention in finding the right way, full of awareness of our noble duty as educators [10].

Art education, especially tembang and folk songs lesson for kindergarten and elementary school age, have important role and function. The important things obtained from the tembang and song are the feeling (affective), the skill (psychomotor), and the thinking (cognitive) [11]. As a medium in forming the character, attitude, and behavior, music, tembang, and songs are not just an entertainment, but a stimulus for emotional intelligence. Furthermore, if the virtue cultivation through tembang and songs from an early age has been instilled properly, it will mold the children who will go to higher education to become students with excellent character. This is in line with the basic values of character education imposed in the higher education 
environment; honest, tough, smart, caring, have high moral standard, creative, excellent, and independent.

\section{CONCLUSSIONS}

The target to be achieved is forming the character of children from an early age, thus are the delicacy of mindfulness, strengthening the sense of nationality, and love and actively studying Javanese literature. Therefore, the tembang as learning material should be suitable according to the age of the children, with the content of literature, the contents of the song, easy understood songs, thus could finally felt by the children. Sufficient understanding of the memorizing song, the meaning of the sentence, and the contents of the tembang, will revive (anggesangaken) the soul of the children (rohing lare) that is in harmony with the life of the nation and state. The right and good character education is expected to produce the good human beings so that they can create a high and dignified culture. The right character education approach will also be perfect if done with a cultural approach, especially the local cultural approach.

\section{REFERENCES}

[1] B. Suharto, Tayub (Pertunjukan dan Ritus Kesuburan). Bandung: Masyarakat Seni Pertunjukan Indonesia, 1999.

[2] M. Barnard, Fashion as Communication: Ways to Communicate Identity, Social, Sexual, Class, and Gender. Yogyakarta: Jalasutra, 2011.

[3] Suharji, "Bedhaya Bedhah Madiun dance: As a tourism superior asset in puro Mangkunagaran," Harmonia: Journal of Arts Research and Education, vol. 17, no. 2, pp. 190-198, 2017.

[4] E. Budy, "The symbolical meaning of Macanan dance in Barongan Blora," Harmonia: Journal of Arts Research And Education, vol. 17, no. 2, pp. 129-135, 2017.

[5] Y. Kusmayadi, "Tradisi Sawer Penganten Sunda Di Desa Parigi Kecamatan Parigi Kabupaten Pangandara," Jurnal Agastya, vol. 8, no. 2, 2018.

[6] A. Juwariyah, "Langen Tayub Padang Bulan" As A Manifestation of Social and Cultural Change in Community," Harmonia: Journal of Arts Research And Education, vol. 18, no. 2, pp. 191-199, 2018.

[7] D. Ayoeningsih, "Makna Simbolis pada Unsur Visual Kostum Tari Topeng Babakan Cirebon Keni Arja di Desa Slangit," Journal of Visual Art and Design, vol. 1, no. 2, pp. 224-245, 2007.

[8] S. Rama, Interpretation of Ahmad Kahfi. Spirituality Transforms With and Outside of One Self. Surabaya: Paramita, 2011.

[9] R. Vetter, "More Than Meets The Eye and Ear: Gamelan and Their Meaning in A Central Javanese Palace," Journal of the Society for Asian Music, vol. XXXII, no. 2, 2001.

[10] E. A. Dice, Western and Chinese New Year's celebrations. New York: Chelsea House, 2009.

[11] Rohana, Penari perempuan dalam Tayub di Blora Jawa Tengah: Sebuah Pendekatan Etnokoreografi. Surakarta: ISI Press Surakarta, 2007. 